\title{
PERAN KEPALA SATUAN KERJA PERANGKAT KOTA (SKPK) DALAM PENCEGAHAN KECURANGAN (FRAUD) (STUDI PENELITIAN PADA SKPK DI KOTA BANDA ACEH)
}

\author{
Dwi Meutia Pertiwi *1 ${ }^{1}$, Syukriy Abdullah ${ }^{* 2}$ \\ ${ }^{1,2}$ Program Studi Akuntansi Fakultas Ekonomi dan Bisnis Universitas Syiah Kuala \\ e-mail: dwimeutiapertiwi@ gmail.com ${ }^{* 1}$, syukriyabdullah@feb.unsyiah.ac.id ${ }^{* 2}$
}

\begin{abstract}
The purpose of this research is to determine how the effort and obstacles for head's SKPK in fraud prevention. This research use descriptive qualitative method with primary data and supported by secondary data. The sample was taken by purposive sampling method and the samples are 14 informants. Data collection technique that used in this research is interview and documentation. Data analysis technique that used in this research is data collection, data reduction, data presentation, drawing conclusion/verification. The results of this research is: 1) Head's SKPK in Banda Aceh have been aware about the importance of fraud prevention measures. The efforts of head's SKPK in fraud prevention is to oversee the application of e-performance and e-procurement sustainably, to make innovations of anti-fraud policies, and creating a culture of honesty and high ethics; 2) The obstacles faced by a head's SKPK in fraud prevention such as the density of activity, inhibition, and its psychological burden.
\end{abstract}

Keywords: The role of a Head's SKPK, Fraud Prevention.

\section{Pendahuluan}

Praktik kecurangan (fraud) telah merasuki berbagai macam aspek kehidupan, berdasarkan buku Report To The Nation, On Occupational Fraud and Abuse yang diterbitkan oleh Association of Certified Fraud Examiners (ACFE) (2014) menjelaskan bahwa fraud is ubiquitous yang artinya kecurangan ada dimana-mana. Meskipun sudah banyak usaha dari berbagai negara untuk menciptakan kontrol anti fraud agar dapat mengurangi kemungkinan dan dampak potensial atas fraud, namun nyatanya tidak ada entitas manapun yang kebal terhadap ancaman ini.

Secara sederhana, fraud dapat diartikan sebagai suatu perbuatan melawan hukum yang dilakukan oleh orang-orang dari dalam dan atau luar organisasi, dengan maksud untuk mendapatkan keuntungan pribadi dan atau kelompoknya yang secara langsung merugikan pihak lain (Tuannakotta, 2007:96). Terkait dengan hal ini, Cressey (1953) dalam Karyono (2013:8), menyebutkan bahwa terdapat tiga faktor yang mendorong seseorang untuk melakukan fraud yaitu: tekanan (pressure), kesempatan (opportunity), dan pembenaran (rationalization).

Di Indonesia fraud berkembang dengan sangat cepat dan meluas serta seperti telah membudaya, dimana fraud terjadi secara berulang-ulang baik pada sektor swasta maupun sektor publik sehingga bagi masyarakat kasus fraud sepertinya bukan rahasia lagi. Thoyibatun (2012) menyatakan bahwa terjadinya fraud membuat organisasi atau instansi yang dikelola menjadi rugi. Untuk itu, Soepardi (2007) mengungkapkan bahwa untuk menghadapi bahaya tersebut, banyak pihak setuju agar tidak memberikan peluang bagi terjadinya fraud melalui berbagai kebijakan. Kebijakan yang dibuat tentunya bertujuan untuk menutup segala bentuk potensi terjadinya fraud.

Fraud sering dikaitkan dengan sistem tata kelola organisasi atau instansi. Senada dengan hal tersebut, Dechow dalam Mahesarani (2015), menyebutkan bahwa insiden fraud tertinggi yaitu pada organisasi atau instansi dengan sistem tata kelola yang lemah. Namun, fenomena yang terjadi saat ini tidak selaras dengan pernyataan tersebut. Buktinya, sistem tata kelola yang dimiliki pemerintah kota Banda Aceh dinilai sudah baik dengan memperoleh opini Wajar Tanpa Pengecualian (WTP) delapan kali berturut-turut (2008-2015) dari Badan Pemeriksa Keuangan Republik Indonesia (BPK-RI) atas Laporan Keuangan Pemerintah Daerah (LKPD), tetapi masih saja terdapat beberapa kelemahan pada LKPD tahun anggaran 2012 seperti kelemahan dalam Sistem Pengendalian Internal (SPI) dan kelemahan administratif (ketidakpatuhan 
terhadap peraturan perundang-undangan, dan ketidakpatuhan dalam pelaporan keuangan) (www.atjehpress.com, 2013). Kelemahan tersebut pada akhirnya berpotensi menyebabkan fraud.

Selain itu, adanya kasus korupsi di Politeknik Aceh yang melibatkan bendahara Wali Kota Banda Aceh semasa almarhum Mawardy Nurdin dengan kerugian negara sekitar Rp 2,3 miliar rupiah dan kasus korupsi dana milik pegadaian Rp 1,8 miliar dengan memberi agunan mobil fiktif (Serambi, 2015).

Dengan munculnya berbagai kondisi tersebut, maka dibutuhkan peran dari masing-masing pimpinan organisasi atau instansi khususnya kepala Satuan Kerja Perangkat Kota (SKPK) untuk mengeksekusinya melalui tindakan pencegahan fraud. Tujuannya agar pencegahan fraud dapat berjalan dengan lebih efektif. Sehubungan dengan hal itu, menurut Loskutovs (2006) bahwa dalam pencegahan fraud di lembaga publik terdapat lima tahapan agar pencegahan fraud dapat lebih efektif, yang salah satunya adalah peran serta atasan.

Apabila fraud tersebut tidak dapat dikurangi atau dicegah, maka akan berakibat fatal bagi organisasi atau instansi tersebut, sehingga dalam kondisi seperti ini posisi sentral berada pada pimpinan. Sebagaimana yang diungkapkan oleh Halim (2012), bahwa pemimpin dapat diberi pengertian sebagai orang yang memimpin dan bertanggung jawab atas suatu organisasi atau salah satu dari sub unitnya. Pimpinan tersebut harus mampu melaksanakan fungsifungsi manajemen, terutama dalam pengambilan keputusan dan kebijakan yang dapat mempermudah pencapaian tujuan dari organisasi atau instansi secara efektif dan efisien terutama dalam hal pencegahan fraud.

\section{Kajian Pustaka}

\section{Kepemimpinan}

\section{Pengertian Kepemimpinan}

Pemimpin adalah inti dari manajemen. Ini artinya manajemen akan tercapai tujuannya jika ada pemimpin. Hal ini menunjukkan bahkan suatu ungkapan yang mendudukkan posisi pemimpin dalam suatu organisasi pada posisi yang terpenting. Pemimpin (leader) pada dasarnya adalah orang yang mampu menggerakkan sumber daya (terutama manusia) untuk bekerja bersama untuk mencapai tujuan. Menurut Jack Welch dalam Slater (2001:33), bahwa pemimpin adalah orang yang memberikan inspirasi dengan visi yang jelas mengenai bagaimana sesuatu dapat dikerjakan dengan cara yang lebih baik. Menurut Halim (2012), bahwa pemimpin dapat diberi pengertian sebagai orang yang memimpin dan bertanggung jawab atas suatu organisasi atau salah satu dari sub unitnya. Dengan kata lain, dapat disimpulkan bahwa pemimpin adalah seseorang yang memiliki kemampuan untuk mengarahkan bawahannya untuk mencapai tujuan organisasi.

Pemimpin dan kepemimpinan adalah sesuatu yang tak dapat dipisahkan, dan merupakan suatu kesatuan. Seorang pemimpin harus mempunyai jiwa kepemimpinan. Kepemimpinan merupakan faktor yang sangat penting dalam mengiring dan mempengaruhi prestasi organisasi (Ardana et al., 2009:89).

Menurut Thoha (2009:121), kepemimpinan adalah aktivitas untuk mempengaruhi perilaku orang lain agar mereka mau diarahkan untuk mencapai tujuan tertentu. Menurut Handoko (2003:294), kepemimpinan merupakan kemampuan yang dipunyai seseorang untuk mempengaruhi orang lain agar bekerja mencapai tujuan dan sasaran.

Dengan kata lain, dapat disimpulkan bahwa kepemimpinan adalah suatu proses untuk mempengaruhi atau menggerakkan orang lain secara efektif dan efisien untuk mencapai tujuan organisasi.

\section{Tipe-Tipe Kepemimpinan}

Tipe kepemimpinan sering disebut perilaku kepemimpinan atau gaya kepemimpinan. Menurut Sanusi dan Sobri (2009:51-59) yaitu:

a) Tipe Otokratik, dimana tipe kepemimpinan ini menganggap bahwa kepemimpinannya adalah hak pribadinya sehingga ia tidak perlu berkonsultasi dengan orang lain dan tidak boleh ada orang lain yang turut campur. Adapun karakteristik dari kepemimpinan tipe ini adalah seorang yang egois, dimana egoismenya akan memutarbalikkan fakta yang ada.

b) Tipe Kendali Bebas, dimana tipe pemimpin yang seperti ini cenderung memilih peran yang pasif dan membiarkan organisasi berjalan menurut temponya sendiri. Disini seorang pemimpin mempunyai keyakinan bahwa dengan memberikan kebebasan yang seluas-luasnya 
terhadap bawahan maka semua usahanya akan cepat berhasil.

c) Tipe Paternalistik, dimana pemimpin yang tergolong sebagai pemimpin yang paternalistik ialah seorang yang menganggap bawahannya sebagai manusia yang tidak dewasa, bersikap terlalu melindungi, jarang memberikan kesempatan kepada bawahannya untuk mengambil keputusan, jarang memberikan kesempatan kepada bawahannya untuk mengambil inisiatif, jarang memberikan kesempatan kepada bawahannya untuk mengembangkan daya kreasi dan fantasinya, dan sering bersikap maha tahu.

d) Tipe Kharismatik, dimana seorang pemimpin yang kharismatik memiliki karakter khusus, yaitu daya tariknya yang sangat memikat sehingga mampu memperoleh pengikut yang sangat besar dan para pengikutnya tidak selalu dapat menjelaskan secara konkret mengapa orang tertentu (pemimpin) itu dikagumi.

e) Tipe Militeristik, dimana pemimpin yang tergolong sebagai pemimpin yang militeristik ialah seorang yang memiliki sifat seperti dalam menggerakkan bawahan lebih sering mempergunakan sistem perintah, dalam menggerakkan bawahan senang bergantung kepada pangkat dan jabatan, senang kepada formalitas yang berlebih-lebihan, menuntut disiplin yang tinggi dan kaku dari bawahan, sukar menerima kritikan dari bawahan, dan menggemari upacara-upacara untuk berbagai keadaan.

f) Pseudo-Demokratik, dimana tipe ini disebut juga dengan semi demokratik, maksudnya pemimpinnya hanya tampaknya saja bersikap demokratis padahal sebenarnya ia bersikap otokratis. Misalnya jika ia mempunyai ide-ide atau konsep yang ingin diterapkan di organisasinya, maka hal tersebut akan dibicarakan atau dimusyawarahkan dengan bawahannya, tetapi situasi diatur dan diciptakan sedemikian rupa sehingga pada akhirnya bawahan didesak agar menerima ide atau konsep tersebut sebagai keputusan bersama.

g) Tipe Demokratik, dimana tipe pemimpin yang demokratik ini ialah dalam proses menggerakkan bawahan selalu bertitik tolak dari pendapat bahwa manusia itu adalah makhluk yang termulia di dunia, selalu berusaha mensikronisasikan kepentingan dan tujuan organisasi dengan kepentingan dan tujuan pribadi dari para bawahan, senang menerima saran/pendapat bahkan kritik dari bawahannya, dan selalu mengutamakan kerjasama dalam usaha mencapai tujuan

Tipe-tipe kepemimpinan di atas dalam praktiknya saling mengisi atau saling menunjang secara bervariasi yang disesuaikan dengan situasinya.

\section{Pencegahan Kecurangan (Fraud) Pengertian Fraud}

Fraud telah mendapatkan banyak perhatian media sebagai dinamika yang sering terjadi. Indikasi adanya fraud dapat dilihat dari bentuk kebijakan yang disengaja dan tindakan yang bertujuan untuk melakukan penipuan atau manipulasi yang merugikan pihak lain (Delfi, 2014).

Adapun pengertian fraud menurut Pusdiklatwas BPKP (2008:11) adalah sebagai berikut:

"Dalam istilah sehari-hari, kecurangan (fraud) dimaknai sebagai ketidakjujuran. Dalam terminologi awam fraud lebih ditekankan pada aktivitas penyimpangan perilaku yang berkaitan dengan konsekuensi hukum, seperti penggelapan, pencurian dengan tipu muslihat, fraud pelaporan keuangan, korupsi, kolusi, nepotisme, penyuapan, penyalahgunaan wewenang, dan lain-lain".

Tuannakotta (2007:96) mendefinisikan fraud sebagai berikut:

"Fraud dapat didefinisikan sebagai suatu perbuatan melawan hukum yang dilakukan oleh orang-orang dari dalam dan atau luar organisasi, dengan maksud untuk mendapatkan keuntungan pribadi dan atau kelompoknya yang secara langsung merugikan pihak lain".

Dengan demikian, secara umum fraud mengandung tiga unsur penting, yaitu: (1) perbuatan tidak jujur, (2) niat atau kesengajaan, dan (3) penipuan yang merugikan orang lain.

Menurut buku Fraud Auditing (1997) dalam Kartini (2000:34), fraud terdiri atas tujuh unsur yang penting., yaitu:

1. Harus terdapat penyajian yang keliru (mispresentation) 
2. Dari suatu masa lampau (past) atau sekarang (present)

3. Faktanya material (material fact)

4. Dilakukan secara sengaja atau tanpa perhitungan

5. Dengan maksud untuk menyebabkan pehak lain bereaksi

6. Pihak yang terlukai harus bereaksi terhadap kekeliruan penyajian

7. Mengakibatkan kerugian

Apabila tidak terdapat salah satu unsur tersebut, maka tidak ada kecurangan yang dilakukan.

\section{Jenis Fraud}

ACFE (2006) dalam Karyono (2013:17), mengkategorikan fraud dalam tiga kelompok yaitu: korupsi (corruption), penyalahgunaan aset (asset misapprotiation), dan pernyataan palsu atau salah pernyataan (fraudulent statement).

\section{Kondisi Penyebab Fraud}

Menurut Arens et al., (2008:370), bahwa fraud yang terjadi dalam organisasi biasanya disebabkan oleh lemahnya kontrol yang dilakukan oleh pihak manajemen. Disamping itu, setiap tindakan fraud juga dipicu dengan adanya tekanan untuk melakukan penyelewengan dan dorongan untuk memanfaatkan kesempatan yang ada dan adanya pembenaran (diterima secara umum) terhadap tindakan tersebut. Hal tersebut senada dengan Cressey (1953) dalam Karyono (2013:8), bahwa terdapat tiga faktor yang mendorong seseorang untuk melakukan kecurangan yang dikenal dengan sebutan "fraud triangle theory", yaitu: (1) tekanan (pressure); (2) kesempatan (opportunity); dan pembenaran (rationalization).

\section{Pengertian Pencegahan Fraud}

Menurut Karyono (2013:47) mendefinisikan pencegahan fraud sebagai berikut :

"Mencegah fraud merupakan segala upaya untuk menangkal pelaku potensial, mempersempit ruang gerak, dan mengidentifikasi kegiatan yang berisiko terjadinya fraud".

Segala bentuk fraud yang terdeteksi harus segera ditindak lanjuti secara tuntas tanpa pandang bulu siapa pelakunya agar mempunyai daya kerja prevention (mencegah). Menurut Fitrawansyah (2014:16) mendefinisikan pencegahan fraud sebagai berikut:
"Pencegahan fraud bisa dianalogikan dengan penyakit, yaitu lebih baik dicegah daripada diobati. Jika menunggu terjadinya fraud baru ditangani itu artinya sudah ada kerugian yang terjadi dan telah dinikmati oleh pihak tertentu dibandingkan bila auditor internal berhasil mencegahnya, tentu kerugian belum semuanya beralih ke pelaku fraud tersebut. Dan bila fraud sudah terjadi maka biaya yang dikeluarkan jauh lebih besar untuk memulihkannya daripada melakukan pencegahan sejak dini."

Menurut Tuanakotta (2007:159) ada ungkapan yang secara mudah ingin menjelaskan penyebab atau akar permasalahan dari fraud, dimana ungkapan itu adalah: fraud by need, by greed and by opportunity. Ungkapan tersebut diartikan jika kita ingin mencegah fraud, hilangkan atau tekan sekecil mungkin penyebabnya.

Sehubungan dengan hal tersebut, menurut Loskutovs (2006) bahwa dalam pencegahan fraud di lembaga publik terdapat lima tahapan agar pencegahan fraud dapat lebih efektif, yaitu: 1) peran serta atasan, 2) pengembangan dan penerapan kode etik, 3) rekrutmen pegawai sesuai peraturan, 4) penyesuaian peraturan dengan kondisi yang terus berkembang, 5) akuntabilitas.

\section{Tujuan Pencegahan Fraud}

Menurut Pusdiklatwas BPKP (2008:38) pencegahan fraud yang efektif memiliki 5 (lima) tujuan yaitu:

1. Preventation

2. Deterence

3. Discruption

4. Identification

5. Civil action prosecution

Fraud merupakan suatu masalah di dalam organisasi atau instansi dan harus dicegah sedini mungkin. Tunggal (2012:59) mengemukakan bahwa terdapat beberapa tata kelola untuk mencegah fraud diantaranya menciptakan budaya jujur dan etika yang tinggi, tanggung jawab manajemen untuk mengevaluasi pencegahan fraud dan pengawasan oleh komite audit.

1. Budaya Jujur dan Etika yang Tinggi

Riset menunjukkan bahwa cara yang paling efektif untuk mencegah dan menghalangi fraud 
adalah mengimplementasikan program serta pengendalian anti fraud, yang di dasarkan pada nilai-nilai inti yang dianut perusahaan. Nilai-nilai semacam itu menciptakan lingkungan yang mendukung perilaku dan ekspektasi yang dapat diterima, bahwa pegawai dapat menggunakan nilai itu untuk mengarahkan tindakan mereka. Nilai-nilai itu membantu menciptakan budaya jujur dan etika yang menjadi dasar bagi tanggung jawab pekerjaan para karyawan. Menciptakan budaya jujur dan etika yang tinggi mencakup enam unsur, yaitu:

a) Menetapkan tone at the top

b) Menciptakan lingkungan kerja yang positif

c) Mempekerjakan dan mempromosikan pegawai yang tepat

d) Pelatihan

e) Konfirmasi

2. Tanggung jawab Manajemen untuk Mengevaluasi Pencegahan Fraud

Fraud tidak mungkin terjadi tanpa adanya kesempatan untuk melakukannya dan menyembunyikan perbuatan itu. Manajemen bertanggung jawab untuk mengidentifikasi dan mencegah fraud, mengambil langkah-langkah yang teridentifikasi untuk mencegah fraud, serta memantau pengendalian internal yang mencegah dan mengidentifikasi fraud.

3. Pengawasan oleh Komite Audit

Komite audit mengemban tanggung jawab utama mengawasi pelaporan keuangan serta proses pengendalian internal organisasi. Dalam memenuhi tanggung jawab ini komite audit memperhitungkan potensi diabaikannya pengendalian internal oleh manajemen serta mengawasi proses pencegahan fraud oleh manajemen, dan program serta pengendalian anti fraud. Komite audit juga membantu menciptakan "tone at the top" yang efektif tentang pentingnya kejujuran dan perilaku etis dengan mendukung toleransi nol manajemen terhadap fraud.

\section{Metode Penelitian Desain Penelitian}

Desain penelitian dalam penelitian ini adalah dengan menggunakan metode penelitian kualitatif dan dengan menggunakan pendekatan yang bersifat deskriptif. Penelitin ini menggunakan data primer dan didukung oleh data sekunder.

\section{Populasi dan Sampel}

Populasi pada penelitian ini adalah Satuan Kerja Perangkat Kota di Kota Banda Aceh yang berjumlah 39 SKPK (termasuk dinas, kantor, badan, kecamatan, dan unit kerja pemerintah). Pemilihan sampel penelitian berdasarkan metode purposive sampling, yaitu memilih sampel berdasarkan berbagai pertimbangan tertentu. Adapun kriteria-kriteria yang digunakan dalam penelitian ini adalah:

1. Pejabat pengguna anggaran/barang daerah pada masing-masig SKPK (1 orang)

2. Sekretaris atau Kepala sub-bagian pada masingmasing SKPK (1 Orang)

3. Hanya SKPK di kota Banda Aceh yang berada di zona hijau dan zona merah di tahun 2013-2014.

Berdasarkan uraian di tersebut, maka SKPK di Kota Banda Aceh yang berada di zona hijau dan zona merah tahun 2013-2014 dapat dilihat pada Tabel 3.1

Tabel 3.1

SKPK di Kota Banda Aceh yang berada di zona hijau dan zona merah tahun 2013-2014

\begin{tabular}{|c|l|c|c|}
\hline \multirow{2}{*}{ No. } & \multicolumn{1}{|c|}{ SKPK } & \multicolumn{2}{c|}{ Berada pada Zona } \\
\cline { 3 - 4 } & \multicolumn{1}{|c|}{ Merah } & Hijau \\
\hline 1. & Dinas Pekerjaan Umum Kota Banda Aceh & & $\sqrt{ }$ \\
\hline 2. & Dinas Pengelolaan Keuangan dan Aset Daerah Kota Banda Aceh & & $\sqrt{ }$ \\
\hline 3. & Dinas Kependudukan dan Pencatatan Sipil Kota Banda Aceh & & $\sqrt{ }$ \\
\hline 4. & Dinas Kesehatan Kota Banda Aceh & $\sqrt{ }$ \\
\hline 5. & Dinas Kebersihan dan Keindahan Kota Banda Aceh & $\sqrt{ }$ & \\
\hline 6. & Kantor Pelayanan Perizinan Terpadu Satu Pintu Kota Banda Aceh & $\sqrt{ }$ \\
\hline 7. & Kantor Lingkungan Hidup Kota Banda Aceh & & \\
\hline
\end{tabular}

Sumber: Humas Pemkot Banda Aceh (2014) 
Setelah dilakukan penyaringan sesuai dengan kriteria di atas, maka yang menjadi sampel dalam penelitian ini dapat dilihat pada Tabel 3.2

Tabel 3.2

Sampel Penelitian

\begin{tabular}{|c|c|c|c|c|}
\hline No. & $\begin{array}{c}\text { SKPK di Kota Banda Aceh Yang } \\
\text { Berada di Zona Hijau dan Zona } \\
\text { Merah Tahun 2013-2014 }\end{array}$ & $\begin{array}{c}\text { Pejabat pengguna } \\
\text { anggaran/barang daerah } \\
(1 \text { Orang })\end{array}$ & $\begin{array}{c}\text { Sekretaris atau Kepala } \\
\text { sub-bagian } \\
\text { (1 Orang) }\end{array}$ & $\begin{array}{c}\text { Jumlah Informan } \\
\text { Pada Masing- } \\
\text { Masing SKPK }\end{array}$ \\
\hline 1. & $\begin{array}{l}\text { Dinas Pekerjaan Umum Kota } \\
\text { Banda Aceh }\end{array}$ & $\sqrt{ }$ & $\sqrt{ }$ & 2 Orang \\
\hline 2. & $\begin{array}{l}\text { Dinas Pengelolaan Keuangan dan } \\
\text { Aset Daerah Kota Banda Aceh }\end{array}$ & $\sqrt{ }$ & $\sqrt{ }$ & 2 Orang \\
\hline 3. & $\begin{array}{l}\text { Dinas Kependudukan dan } \\
\text { Pencatatan Sipil Kota Banda Aceh }\end{array}$ & $\sqrt{ }$ & $\sqrt{ }$ & 2 Orang \\
\hline 4. & Dinas Kesehatan Kota Banda Aceh & $\sqrt{ }$ & $\sqrt{ }$ & 2 Orang \\
\hline 5. & $\begin{array}{l}\text { Dinas Kebersihan dan Keindahan } \\
\text { Kota Banda Aceh }\end{array}$ & $\sqrt{ }$ & $\sqrt{ }$ & 2 Orang \\
\hline 6. & $\begin{array}{l}\text { Kantor Pelayanan Perizinan } \\
\text { Terpadu Satu Pintu Kota Banda } \\
\text { Aceh }\end{array}$ & $\sqrt{ }$ & $\sqrt{ }$ & 2 Orang \\
\hline 7. & $\begin{array}{l}\text { Kantor Lingkungan Hidup Kota } \\
\text { Banda Aceh }\end{array}$ & $\sqrt{ }$ & $\sqrt{ }$ & 2 Orang \\
\hline
\end{tabular}

Sumber: Data Diolah (2016)

Tabel 3.2 menjelaskan bahwa yang menjadi sampel penelitian dalam penelitian ini berjumlah 14 orang informan.

\section{Teknik Pengumpulan Data}

1. Wawancara, dimana dalam penelitian ini peneliti menggunakan teknik wawancara terstruktur, dimana peneliti terlebih dahulu mempersiapkan daftar pertanyaan dan kemudian ditanyakan kepada 14 orang yang menjadi informan penelitian di masing-masing lokasi penelitian.

2. Dokumentasi, dimana dalam penelitian ini penulis menggunakan berbagai macam dokumen-dokumen untuk memperoleh data primer, yeng meliputiu: pedoman wawancara, voice recorder, dan surat rekomendasi penelitian.

\section{Teknik Analisis Data}

Adapun teknik analisis kualitatif yang digunakan dalam penelitian ini ialah model analisis interaktif yang dikembangkan oleh Miles dan Hubermann (1992) dalam Sugiyono (2011:335), yang terdiri dari langkah-langkah sebagai berikut:
1. Pengumpulan data

2. Reduksi data

3. Penyajian data

4. Penarikan kesimpulan

\section{Hasil dan Pembahasan}

Bagaimana Upaya Kepala Satuan Kerja Perangkat Kota (SKPK) dalam Pencegahan Kecurangan (Fraud) (Studi Penelitian pada SKPK di Kota Banda Aceh)

\section{Mengenai Manfaat Sarana Pencegahana Fraud}

Fraud dapat terjadi kapan saja dan dimana saja, sehingga ini menjadi seperti sesuatu yang menakutkan bagi organisasi atau instansi. Fraud seharusnya dapat dicegah sedini mungkin agar dampak yang ditimbulkan tidak terlalu fatal. Menurut Tuannakotta (2007:96), bahwa fraud dapat didefinisikan sebagai suatu perbuatan melawan hukum yang dilakukan oleh orang-orang dari dalam dan atau luar organisasi, dengan maksud untuk mendapatkan keuntungan pribadi dan atau kelompoknya yang secara langsung merugikan pihak lain. Oleh sebab itu, kegiatan pencegahan fraud menjadi suatu kebutuhan bagi 
setiap organisasi atau instansi untuk mengamankan sumber daya yang dimilki dan menjaga kepercayaan publik. Hal ini sejalan dengan hasil wawancara peneliti bersama kepala SKPK di masing-masing SKPK di Kota Banda Aceh, sebagai berikut:

"Pencegahan kecurangan perlu untuk dilakukan, apalagi kecurangan terhadap waktu. Nah, takutnya dapat memperburuk kinerja dinas ini. Apalagi aktivitas di dinas ini lebih kepada memberikan pelayanan”. (Informan 3, Selasa/26 April 2016 ).

Fraud diibaratkan seperti penyakit yang susah untuk disembuhkan, maka dari itu untuk menangani penyakit lebih baik mencegah daripada mengobatinya. Tuanakotta (2007:159), menyebutkan bahwa ada ungkapan yang secara mudah ingin menjelaskan penyebab atau akar permasalahan dari fraud, dimana ungkapan itu adalah: fraud by need, by greed and by opportunity. Ungkapan tersebut diartikan jika kita ingin mencegah fraud, hilangkan atau tekan sekecil mungkin penyebabnya. Hal ini sejalan dengan hasil wawancara peneliti bersama kepala SKPK di masingmasing SKPK di Kota Banda Aceh, sebagai berikut:

"Iya tentu saja, karena tanpa kita sadari dengan mencegah kita sudah dapat mempersempit gerak langkah dari orang-orang yang ingin memanfaatkan situasi dilingkungannya berada". (Informan 1, Senin/16 Mei 2016).

Dengan kata lain, dapat disimpulkan bahwa kepala SKPK di Kota Banda Aceh telah menyadari akan pentingnya tindakan pencegahan fraud, misalnya dengan mencegah secara tidak langsung dapat menolak atau menahan segala bentuk fraud yang mungkin terjadi dengan cara menghilangkan atau menekan sekecil mungkin penyebabnya. Menurut Cressey (1953) dalam Karyono (2013:8), terdapat tiga faktor yang mendorong seseorang untuk melakukan kecurangan yang dikenal dengan sebutan "fraud triagle", yaitu: (1) tekanan (pressure); (2) kesempatan (opportunity); dan pembenaran (rationalization).

\section{Mengenai Bentuk Sarana Pencegahan Fraud}

Dalam rangka pencegahan fraud, pemerintah kota Banda Aceh pada dasarnya telah berupaya untuk mencegah terjadinya fraud sedini mungkin melalui penerapan sistem pencegahan fraud seperti sistem ekinerja, e-procurement, dan penetapan zona integritas (Humas Setda, 2012).
Namun, untuk membantu keberhasilan penerapan sistem pencegahan fraud tersebut tentu perlu adanya intervensi dari seluruh kepala SKPK di Kota Banda Aceh. Sebagaimana yang dijelaskan oleh Loskutovs (2006), bahwa dalam pencegahan fraud di lembaga publik terdapat lima tahapan agar pencegahan fraud dapat lebih efektif, yang salah satunya melalui peran serta atasan. Adapun salah satu cara yang dilakukan kepala SKPK di kota Banda Aceh dengan terus berupaya mengawasi pengaplikasian sistem ekinerja dan e-procurement oleh bawahannya sebagai salah satu bentuk pencegahan fraud di lingkungannya. Hal ini sejalan dengan hasil wawancara peneliti bersama kepala SKPK di masing-masing SKPK di Kota Banda Aceh, sebagai berikut:

"Upayanya ya... mengawasi pengisian e-kinerja dan e-procurement sebagai bukti pertanggung jawaban mereka terhadap kegiatan yang dilakukan setiap harinya. Apalagi dinas PU ini banyak menangani proyek-proyek dengan anggaran yang digunakan relatif besar untuk satu proyek". (Informan 1, Senin/16 Mei 2016).

Namun disamping itu, kepala SKPK di Kota Banda Aceh juga terus berupaya melakukan inovasiinovasi terhadap kebijakan anti fraud yang disesuaikan pada kebutuhan instansinya masing-masing. Hal ini sejalan dengan hasil wawancara peneliti bersama kepala SKPK di masing-masing SKPK di Kota Banda Aceh, sebagai berikut:

"Dinas ini kebanyakan kegiatannya di luar kantor, misalnya ada proyek aspal jalan yang berlubang. Nah, saat itulah saya menganjurkan kepada setiap bidang yang bertanggung jawab atas proyek itu untuk turun langsung mengawasi proyek yang sedang di kerjakan gunanya untuk memastikan apakah proyek tersebut dikerjakan sesuai prosedur dan tepat waktu." (Informan 1, Senin/16 Mei 2016) "Di dinas ini ada namanya program e-pju, gunanya untuk menginput masalah material, jadwal angkut sampah, sampai dengan tindak lanjutnya. Melalui e-pju ini semuanya bisa terdata sehingga pada saat nanti dibukukan jadi lebih mudah dan jelas. dan tentunya e-pju ini juga dapat diakses oleh masyarakat". (Informan 5, Jum'at/13 Mei 2016).

"Saya ada menerapkan program shalat dhuha setelah apel pagi sebelum menjalankan tugas, asumsinyanya jika kita sudah taat kepada Allah 
SWT maka insya allah kita bisa taat kepada aturan yang ada misalnya untuk tidak berbuat curang pastinya. Nah, yang kedua di setiap bulannya saya juga ada memanggil ustad untuk memberikan siraman rohani bagi pegawai di kantor ini termasuk saya". (Informan 6, Senin/25 April 2016).

Dengan kata lain, dapat disimpulkan bahwa bentuk sarana pencegahan fraud yang dilakukan oleh kepala SKPK di Kota Banda Aceh yaitu dengan melakukan pengawasan secara berkesinambungan terhadap pengaplikasian e-kinerja dan e-procurement. Disamping itu, ia juga melakukan inovasi-inovasi seperti melaksanakan program pembinaan akhlak, membangun sistem aplikasi elektronik, dan berupaya mengawasi langsung program atau kegiatan di lapangan.

\section{Mengenai Strategi Untuk Mengoptimalkan Sarana Pencegahan Fraud}

Agar sarana pencegahan fraud yang sudah diterapkan tersebut dapat terus berjalan secara berkesinambungan, tentunya kepala SKPK di Kota Banda Aceh tetap harus berupaya untuk mengoptimalkannya. Adapun salah satu cara yang selama ini dilakukan oleh kepala SKPK di kota Banda Aceh yaitu dengan memperbaiki tata kelola atas SKPK yang dipimpinnya. Menurut Tunggal (2012:59) mengemukakan bahwa terdapat beberapa tata kelola untuk mencegah fraud diantaranya menciptakan budaya jujur dan etika yang tinggi, tanggung jawab manajemen untuk mengevaluasi pencegahan fraud dan pengawasan oleh komite audit. Sehubungan dengan hal tersebut, upaya kepala SKPK untuk mengoptimalkan sarana pencegahan fraud sangat bervariasi. Hal ini sejalan dengan hasil wawancara peneliti bersama kepala SKPK di masing-masing SKPK di Kota Banda Aceh, sebagai berikut:

"Biasanya saya mengadakan rapat bulanan bersama setiap bidang untuk membahas isu-isu kedepan berdasarkan masukan dari masyarakat dan mengevaluasi kegiatan serta pertanggungjawaban atas pelaksanaannya dari masing-masing bidang". (Informan 1, Senin/16 Mei 2016).

"Pertama kita tempatkan pegawai sesuai latar belakang pendidikan atau keahliannnya masingmasing. Disamping mereka sudah paham dengan tupoksinya masing-masing, saya juga tetap berusaha untuk dapat memantau kerja mereka setiap hari walaupun hanya sekedar bertanya sedang mengerjakan apa dan ada kendala apa yang sedang dihadapi mereka". (Informan 2, Rabu/3 Mei 2016).

"Istilahnya gini dik, kita tidak mungkin memaksa pegawai untuk tidak bersikap curang karena saya rasa udah sama-sama dewasa. Jadi, saya dulu yang harus bisa menjadi tauladan agar mereka termotivasi untuk tidak curang. Contoh kecilnya gini dik, saya berusaha untuk datang dan pulang tepat waktu, dengan harapan mereka juga demikian. Selain itu, saya juga berusaha untuk dapat memantau kegiatan pegawai setiap hari dan mengevaluasi setiap bulannya". (Informan 3, Selasa/26 April 2016 ).

"Saya berusaha mengadakan rapat untuk mengecek sekaligus mengevaluasi program dan anggaran yang sudah terpakai. Selain itu, saya juga berusaha untuk melakukan pendekatan emosional yang baik dengan mereka agar tidak ada batasan antara atasan bawahan". (Informan 4, Selasa/17 Mei 2016).

"Saya menempatkan diri sejajar dengan mereka dan bukan sebagai "bos" agar mereka bisa lebih terbuka dan bebas beragumen. Selain itu juga saya tetap bersikap tegas dengan memberikan teguran secara lisan maupun tulisan bagi yang tidak disiplin (misalnya ketika jam kerja mereka belum ada di ruangan nah itu biasanya saya telepon dulu, kalau diulang lagi saya tegur, tapi kalau masih tidak disiplin juga nama mereka ditempel bahkan sampai dikirim ke BKPP untuk ditindak lanjuti). Kemudian saya juga ada melakukan pembinaan pegawai setiap hari selasa (seperti nasihat dan informasi lain yang menyangkut pekerjaan) dan juga ada mengadakan rapat monev setiap bulannya untuk mengevaluasi pekerjaan yang sudah dilakukan baik itu pekerjaan lapangan maupun di dalam kantor dimana setiap bidang harus mempresentasikan hasilnya. Selain itu, saya juga ada memberikan reward kepada pegawai yang disiplin (seperti biaya pembinaan dan sertifikat)". (Informan 5, Jum'at/13 Mei 2016).

"Sejauh ini yang saya lakukan dengan berusaha menempatkan diri sebagai teman mereka, kemudian seminggu sekali pasti saya mengecek dan mengevaluasi langsung hasil kerja seluruh pegawai dengan meminta password e-kinerja mereka masing-masing. Selain itu, saya juga ada 
memberikan sanksi seperti menunda pemberian SPPD bagi pegawai sangat tidak disiplin serta memberikan reward tapi bukan dalam bentuk uang hanya dalam bentuk hiburan saja (seperti mengajak mereka untuk makan-makan atau sekedar ngopi bersama-sama di luar jam kantor)". (Informan 6, Senin/25 April 2016).

"Pastinya dengan memberikan dorongan, motivasi, dan juga terus mengayomi seluruh pegawai untuk bisa bekerja sesuai aturan. Selain itu, mengadakan rapat untuk mengevaluasi pekerjaan yang sudah berjalan setiap bulan atau sesuai dengan kebutuhan". (Informan 7, Rabu/13 April 2016 ).

Dengan kata lain, maka dapat disimpulkan bahwa sejauh ini strategi kepala SKPK di Kota Banda Aceh untuk mengoptimalkan sarana pencegahan fraud yaitu dengan cara menciptakan budaya jujur dan etika yang tinggi. Dengan menciptakan budaya jujur dan etika yang tinggi dapat membantu sebuah organisasi atau instansi untuk mengantisipasi atau mencegah fraud sedini mungkin. Hal ini senada dengan penelitian Kurniawan (2014) bahwa penciptaan lingkungan budaya jujur berpengaruh signifikan negatif terhadap kecenderungan kecurangan. Artinya semakin baik upaya penciptaan lingkungan budaya jujur di dalam perusahaan maka kemungkinan terjadinya kecurangan semakin kecil, begitu juga sebaliknya.

Dari keseluruhan komponen yang terkait dalam budaya jujur dan etika yang tinggi tersebut, maka kepala SKPK di Kota Banda Aceh cenderung melakukan 3 hal yaitu kegiatan konfirmasi, menciptakan lingkungan kerja yang positif, dan tone at the top sebagai strategi untuk mengoptimalkan sarana pencegahan fraud. Namun, disisi lain kegiatan pelatihan kepada pegawai cenderung tidak dilakukan oleh kepala SKPK secara langsung karena kegiatan pelatihan diberikan langsung oleh BKPP berdasarkan usulan dari kepala SKPK secara bergilir untuk setiap pegawainya.

\section{Bagaimana Kendala Kepala SKPK dalam Pencegahan Fraud (Studi Penelitian pada SKPK di Kota Banda Aceh)}

Sebagai seorang pimpinan kepala SKPK tentunya harus memiliki jiwa kepemimpinan agar dapat menjalankan instansi yang dipimpinnya dengan baik. Dalam kondisi seperti ini, kepala SKPK membutuhkan pegawainya untuk bersama-sama bekerja demi satu tujuan. Menurut Handoko (2003:294), kepemimpinan merupakan kemampuan yang dipunyai seseorang untuk mempengaruhi orang lain agar bekerja mencapai tujuan dan sasaran.

Sejauh ini kepala SKPK di Kota Banda Aceh sudah berusaha mengarahkan pegawainya untuk menjauhi praktik fraud. Dalam hal ini kepala SKPK sudah membangun sarana pencegahan fraud dan juga mengoptimalkannya, namun tidak jarang kepala SKPK dihadapkan pada situasi yang dapat membatasinya dalam melakukan hal tersebut. Hal ini sejalan dengan hasil wawancara peneliti bersama kepala SKPK di masing-masing SKPK di Kota Banda Aceh, sebagai berikut:

"Hambatannya, masih ada rasa segan yang tidak beralasan dari saya, karena hubungan antara saya dengan pegawai sudah sangat dekat. Sehingga apabila ada pegawai yang melakukan penyimpangan saya agak sedikt segan aja, tapi tetap saya tegur dengan cara saya agar tidak menyinggung mereka". (Informan 6, Senin/25 April 2016).

"Mungkin, hambatannya karena ada beban psikologis yang saya rasakan bila saya tidak dapat konsekuen dan konsisten dalam menegakkan aturan”. (Informan 5, Jum'at/13 Mei 2016).

"Hambatannya mungkin karena kesibukan saya sendiri, yang terkadang buat saya jarang bisa memantau kegiatan pegawai tetapi tetap saya pantau semampu saya”. (Informan 2, Rabu/3 Mei 2016).

Dengan kata lain, dapat disimpulkan bahwa tidak jarang kepala SKPK di kota Banda Aceh merasa ada beberapa hal yang menjadi kendala bagi dirinya dalam pencegahan fraud yaitu:

1. Padatnya aktivitas yang dimilikinya sehingga ia tidak dapat terus menerus mengawasi aktivitas pegawainya

2. Adanya rasa segan untuk menegur bawahan karena kedekatan emosional yang dimilikinya

3. Beban psikologis yang dialaminya bila tidak dapat konsekuen dan konsisten dalam menegakkan aturan.

Namun, dalam hal ini bukan berarti kepala SKPK tidak berupaya melakukan pencegahan fraud hanya saja kepala SKPK di Kota Banda Aceh tetap menyesuaikan dengan caranya sendiri. 


\section{Kesimpulan}

Berdasarkan pembahasan hasil penelitian yang telah dikemukakan sebelumnya, dapat disimpulkan bahwa:

1) Kepala SKPK di Kota Banda Aceh telah menyadari akan pentingnya tindakan pencegahan fraud. Adapun upaya kepala SKPK di Kota Banda Aceh dalam pencegahan fraud yaitu dengan terus berupaya mengawasi pengaplikasian sistem ekinerja dan e-procurement secara berkesinambungan. Disamping itu, ia juga melakukan inovasi-inovasi terhadap kebijakan anti fraud sesuai dengan kebutuhan seperti melaksanakan program pembinaan akhlak, membangun sistem aplikasi elektronik, dan berupaya mengawasi langsung program atau kegiatan di lapangan. Bukan hanya itu saja, ia juga memiliki strategi untuk mengoptimalkannya, seperti menciptakan budaya jujur dan etika yang tinggi yaitu melalui kegiatan konfirmasi, menciptakan lingkungan kerja yang positif, dan tone at the top.

2) Kendala yang dihadapi kepala SKPK dalam pencegahan fraud, yaitu: adanya kepadatan aktivitas, rasa segan, dan beban psikologis yang dimilikinya.

\section{Daftar Pustaka}

Arens, Alvin A., Randal J Elder., dan Mark S Beasley. 2008. Auditing dan Jasa Assurance (Terjemahan Herman Wibowo). Jakarta: Erlangga.

Association of Certified Fraud Examiner (ACFE). 2014. Report To The Nations: On Occupational Fraud And Abuse. Melalui https://www.acfe.com/rttn/ docs/2014report-to-nations.pdf. Diakses tanggal 17 Juli 2016.

Atjehpress. 2013. Inilah Temuan BPK RI di Pemkot Banda Aceh. Melalui http://atjehpress.com/2013/ 05/inilah-temuanbpk-ri-di-pemko-banda-aceh. Diakses tanggal 17 Juli 2016.

Delfi, Tiara. 2014. Pengaruh Efektivitas Penendalian Internal dan Kesesuaian Kompensasi terhadap Kecenderungan Akuntansi. Skripsi. Riau: Universitas Riau.
Fitrawansyah. 2014. Fraud \& auditing. Jakarta: Mitra Wacana Media.

Halim, Rahmawati. 2012. Pengaruh Komitmen Organisasi dan Peranan Kepemimpinan dalam Meningkatkan Pengelolaan Keuangan Daerah pada Dinas Pendapatan Pengelolaan Keuangan dan Aset Kabupaten Banggar Kepulauan. Jurnal Academica Fisip Untad. Vol.4, No.1: 816-829.

Handoko, T Hani. 2003. Manajemen Sumber Daya Manusia. Bandung: Salemba Empat.

Humas Pemkot Banda Aceh. 2014. Banda Aceh Raih Penghargaan Kepatuhan Pelayanan Publik. Melalui https://www.bandaacehkota.go.id/ berita/ 631/banda-aceh-raih-penghargaankepatuhan-pelayanan-publik.html.Diakses tanggal 5 Januari 2016.

Karyono. 2013. Forensic Fraud. Yogyakarta: Penerbit Andi.

Kurniawan, Rahmat. 2014. Pengaruh Penciptaan Lingkungan Budaya Jujur Terhadap Kecenderungan Kecurangan (Studi Empiris pada Perusahaan BUMN di Kota Padang). Skripsi. Padang: Universitas Negeri Padang.

Loskutovs, Aleksejas. 2006. Ethics, Integrity, and Accountability in the Public Sector: Corruption United Nations. Russia: St. Petersburg.

Mahesarani, Dwi Shinta. 2015. Pengaruh Tata Kelola Perusahaan Terhadap Potensi Kecurangan Laporan Keuangan. Skripsi. Semarang: Universitas Diponegoro.

Pusdiklatwas BPKP. 2008. Fraud Auditing. Bogor: Badan Pengawas Keuangan dan Pembangunan.

Sanusi, Achmad dan Sobri Sutikno. 2009. Kepemimpinan Sekarang dan Masa Depan dalam Membentuk Budaya Organisas yang Efektif. Bandung: Prospect.

Serambi. 2015. Elfina dipecat dari PNS Pemko Banda Aceh. 15 November hal.3.

Slater, Robert. 2001. Jack Welch and The GE Way: Wawasan Manajemen dan Rahasia Kepemimpinan CEO Legendaris (Terjemah oleh Fandy Tjiptono). Yogyakarta: Andi.

Soepardi, Eddy Mulyadi. 2007. Memahami akuntansi keuangan. Jakarta: Raja Grafindo Persada. 
Sugiyono. 2011. Metode Penelitian Bisnis

(Pendekatan Kuantitatif, Kualitatif, dan $R \& D)$. Bandung: Alfabeta.

Thoha, Miftah. 2009. Kepemimpinan dalam Manajemen. Jakarta: PT RajaGrafindo Persada.

Thoyibatun, Siti. 2012. Faktor-Faktor Yang Berpengaruh Terhadap Perilaku Tidak Etis Dan Kecenderunagn Kecurangan Akuntansi Serta Akibatnya Terhadap Kinerja Organisasi. Jurnal Ekonomi \& Keuangan. Vol. 16, No. 2: 245-260.

Tuanakotta, Theodorus M. 2007. Akuntansi Forensik dan Audit Investigatif. Jakarta: Salemba Empat.

Tunggal, Amin Widjaja. 2012. Mencegah Dan Mendeteksi Kecurangan Akuntansi. Jakarta: Harvarindo. 